\title{
Research on the Optimization of Teaching System of International Economy and Trade
}

\section{Shuo Tian* Lianggui Zhang Haiwei Zhang}

School of Economics, Shandong University of Technology, Zibo, Shandong, 255012, China

\section{ARTICLE INFO}

Article history

Received: 13 November 2020

Revised: 20 November 2020

Accepted: 9 April 2021

Published Online: 16 April 2021

Keywords:

New liberal arts

International economy and trade

Optimization of teaching system

Cross border e-commerce direction

\section{Introduction}

The development of Internet and data technology hastens the birth of new industries. The integration of information technology and humanities and social sciences has become an international trend. The construction of new liberal arts is the practice of the cross integration of philosophy and social sciences and scientific and technological revolution in higher education ${ }^{[1]}$. The cultivation of comprehensive and applied talents is the support to realize the major education strategy of "new liberal arts". The new international trade state represented by cross-border e-commerce is developing rapidly, which also gives birth to new requirements for the cultivation of international

\section{ABSTRACT}

Taking the construction of new liberal arts as a background, this paper proposes that the international economy and trade major should optimize the teaching system and personnel training mechanism by adding the new cross-border e-commerce direction. This paper highlights the development path of high-quality international economy and trade professional training, and further ensures the first-class talent training and first-class professional construction specialty. economic and trade professionals. It is not only an important measure of cross-border trade reform, but also a new round of cross-border trade reform and innovation ${ }^{[4]}$.

\section{Review of the Construction of Internation- al Economy and Trade}

The author's school is a local university. The major of international economy and trade always adheres to the principle of "people-oriented", promotes the "four regression", adheres to the problem-oriented and quality standards, and is committed to training professionals who master international economic and trade theories, are familiar with international economic and trade rules and

\footnotetext{
*Corresponding Author:

Shuo Tian,

School of Economics, Shandong University of Technology, Zibo, Shandong, 255012, China;

E-mail: yutiants@163.com.
}

Fund Project:

This paper was supported by Laboratory construction project of Shandong University of Technology "Cross border e-commerce B2C platform product operation simulation experiment construction" (2020018). 
national foreign economic policies and regulations, have strong import and export operation ability. The author's school adhere to cultivate comprehensive and applied talents with broad open vision, solid foreign language skills, good communication skills, lofty sense of social responsibility, good professional ethics, strong social adaptability and innovation ability, who are competent for foreign-related business or management positions. On the basis of detailed implementation of the comprehensive reform plan of undergraduate education and teaching, the major has carried out the project of improving the quality of undergraduate talents training, focused on major construction, curriculum construction, classroom teaching, practical teaching, teaching management linkage and other key work, and constructed a long-term mechanism for revitalization of undergraduate education.

Since its establishment in 1990, this major has made remarkable achievements in teaching, scientific research and social services. In 2011, it was awarded the characteristic specialty of Shandong colleges and universities, and in 2013, it was established as the construction specialty of Shandong Provincial applied talents training characteristic famous university. Relying on Shandong industrial economy research base, the provincial social science research base of the college, remarkable achievements have been made in serving the society and promoting teaching. In 2017 , it was recognized as the core specialty of high-level application-oriented construction specialty (Group) in Shandong Province. In 2020, it was identified as the first batch of first-class undergraduate specialty construction points at the national level. At present, there are obvious advantages in the construction of international economic and trade courses, including one national bilingual teaching demonstration course, one brand course of English teaching by the Ministry of education in China, and seven excellent courses in Shandong Province. A relatively reasonable structure of high-level teachers has been formed, including one famous teacher in Shandong Province: There is one famous teacher at the university level, and one of them enjoys the subsidy of the State Council. The teaching system is relatively complete, forming a complete teaching level for undergraduate, master and overseas students, and an effective cooperation mechanism between school and enterprise and school local government has been established, and the open school running is fruitful. To sum up, the professional orientation, characteristics and achievements of international economy and trade specialty are the basic guarantee for further optimizing the talent training mode of the major and the driving force for the specialty to continue to move forward.

The following contents of this paper are arranged as follows: (1) based on the relevant requirements of the construction of new liberal arts and adapting to the new situation of international trade development, accurately positioning the training objectives of international economic and trade talents under the new situation, and clarifying the current training scheme, especially the short board of cross-border e-commerce talents training; (2) based on the short board analysis, from the curriculum system, practical teaching, teaching staff, etc In terms of optimization, the paper puts forward the construction ideas and relevant measures for the cross-border e-commerce direction of international economy and trade.

\section{Analysis of the Problems in Specialty Con- struction under the Background of New Lib- eral Arts}

Although in recent years, the major of international economy and trade has carried out comprehensive reform in many aspects around the core goal of high-level applied talents, there are still some defects in the construction of international economy and trade major combined with the construction background of new liberal arts.

First of all, the teaching content is relatively backward. In recent years, with the development of global integration, cross-border e-commerce has developed continuously. Customs, commodity inspection and other aspects related to it are significantly different from the traditional trade form, and are in the state of changing with each passing day, which inevitably requires the curriculum of international economy and trade to adapt to the development of new formats exhibition needs. Although the international economics and trade major of the author's university updated the training program to a large extent in 2019, adding cross-border e-commerce course modules, offering cross-border e-commerce theory and practice, cross-border e-commerce payment and settlement, cross-border e-commerce data analysis and other courses, the construction of the curriculum system is still in the exploratory stage, and there is still a large space for optimization.

Secondly, the proportion of practice teaching is biased. At present, in the process of international economy and trade professional education, there are the phenomena of "emphasizing theory, ignoring practice" and "emphasizing knowledge and neglecting ability". In the existing practice courses, the training mode is relatively backward, lacking practice teaching platform and software, and the effect of practice teaching in off campus base is not good. Therefore, the scientific and advanced nature of practical teaching in the international economy and trade specialty of the 
author's school needs to be improved. In the process of new liberal arts construction, the proportion of practical courses should be appropriately increased, so as to serve the cultivation of applied talents.

Thirdly, the construction of teaching staff needs to be strengthened. The teaching staff is an important factor in determining the teaching effect. At present, the proportion of "double qualified" teachers in the Department of international economics and trade of the author's unit is relatively low. The newly recruited doctors attach more importance to scientific research and theoretical teaching, generally lack of working experience in enterprises and lack of understanding of the development of cross-border e-commerce industry, so the effect of practical teaching is not good.

\section{Analysis of Construction Ideas and Related Measures}

Based on the above short board analysis in the original teaching system and the overall requirements of the construction of new liberal arts, the project plans to design reform plans one by one from the aspects of curriculum system, practical teaching and teaching staff.

First of all, optimize the professional curriculum system and form, and promote interdisciplinary integration. The construction of new liberal arts should carry out the fundamental task of establishing morality and cultivating talents, continue to optimize the curriculum system, attach importance to quality education and general education, and cultivate students' interdisciplinary thinking and problem-solving ability. Through in-depth understanding of the requirements of enterprises for the knowledge structure of international economic and trade professionals, and visiting domestic and international economic and trade professional talents training institutions with good results, the curriculum system and content in the original talent training program are integrated ${ }^{[2]}$. In the form of curriculum organization, we should promote the deep application of information technology in teaching, extensively carry out online and offline hybrid learning, make full use of the high-quality curriculum resources of famous teachers and universities, change the traditional teaching material + Classroom + indoctrination mode, and make the curriculum form more three-dimensional, visual and intelligent. Internet, big data and AI technology are introduced into the international economic and trade specialty courses, such as "Internet plus international trade", "big data + international trade" and so on ${ }^{[3]}$.

Secondly, construct practical experimental teaching system. We should strengthen the practical teaching and construct the three-level practical teaching system of "class, competition and practice". Starting from the ability requirements of social development for international economic and trade professionals, with the help of the laboratory platform, the mode of "enterprise situation, project leading" is adopted for training, and the whole process of training students from basic skills training to project development and post ability literacy is completed ${ }^{[5]}$. Organize students to participate in the discipline competition, stimulate students' interest in learning and sense of competition, and cultivate team spirit. In addition, we should strengthen the construction of characteristic specialty direction, special laboratory, practice and employment base, encourage students to participate in practice, and improve their professional ability through "learning by doing" on the $\operatorname{spot}^{[8-9]}$.

Thirdly, strengthen the integration of production and education, and attach importance to collaborative education. With the rapid development of mobile Internet, big data, cloud computing, artificial intelligence and other information technologies, the existing teachers of this major independently complete the task of cultivating application-oriented talents. Based on the existing experience of school enterprise integration development, we should deepen cross industry and field cooperation to form a collaborative education network. Specific measures are as follows: Cooperate with powerful and willing enterprises to build standardized training base. Create conditions for professional teachers to deeply participate in the actual business, and at the same time employ enterprise staff or experts to attend lectures or lectures in the school, so as to make up for the lack of practical work experience of professional teachers and build a new teaching system. We should bring the international cooperation projects into the undergraduate talent training system, scientifically and reasonably design the training mode and program of international cooperation, and increase the support of international cooperation and exchange for undergraduate teaching.

Fourthly, vigorously promote innovation and entrepreneurship education. Guided by the cultivation of innovative spirit, entrepreneurial consciousness and innovative ability, we will comprehensively deepen the reform of talent training mode and teaching methods ${ }^{[7]}$. Specific measures: (1) Strengthen the construction of innovation and entrepreneurship education system and organization, and introduce the management measures of innovation and entrepreneurship education. (2) We should strengthen the construction of College Students' Entrepreneurship incubation base, give full play to the function of College Students' maker laboratory, and create a national virtual 
simulation experimental center. (3) We will promote the construction of innovation and entrepreneurship basic courses, innovation and entrepreneurship case and experiment courses, and innovation and entrepreneurship ability courses, and integrate innovation and entrepreneurship education into the whole process of talent training. (4) We will strengthen the construction of innovation and entrepreneurship teaching staff, establish a temporary training system for relevant professional teachers and full-time teachers for innovation and entrepreneurship education in enterprises, employ well-known experts and scholars and successful people in the industry to teach part-time, and establish a full-time and part-time teaching staff for innovation and entrepreneurship education ${ }^{[6]}$.

\section{References}

[1] Huo Qianqian. Research on teaching reform of international economy and Trade Major under the background of cross-border e-commerce [J]. Times economic and trade, 2020 (20): 102-103.

[2] Hu Junwen, Dai Jin, ye yuan. Research on practice teaching reform of international economy and Trade Specialty_ Based on cross border e-commerce innovation and entrepreneurship practical platform [J]. Journal of Jiangsu Vocational and Technical College of economics and trade, 2017 (06): 79-82.

[3] Jiang Yulian, Li Qing. Research on the talent training mode of international economy and trade in the era of cross border E-commerce — Taking Hezhou University as an example [J]. Modern business in- dustry, 2019,40 (33): 64-65.

[4] Ni Lin. Research on talent training reform of international economy and trade under the background of "cross border e-commerce" —_ Taking International Trade Major of School of Applied Technology of Suzhou University as an example [J]. E-commerce, 2016 (11): 71-72.

[5] Wang Qing. New thinking on practical teaching mode of international economy and trade under cross border e-commerce environment $[\mathrm{J}]$. Foreign trade, 2020 (01): 144-147.

[6] Wang Suyu, Wanyu, Lixin. Difficulties and Countermeasures for cross-border e-commerce talents training in international economic and trade major transformation [J]. Quality and market, 2020 (11): 25-27.

[7] Wu Jin. Research on the development direction of international economy and trade under the background of cross border e-commerce $[\mathrm{J}]$. Bohai rim economic outlook, 2018 (10): 31.

[8] Xie Yuan. Research on the practice teaching reform of international economy and Trade Specialty in Higher Vocational Colleges under the background of cross-border e-commerce [J]. Science and education guide, 2019 (06): 52-53 + 65 .

[9] Zhu Qiaoyan. Research on teaching reform and practice of international economy and Trade Specialty in Higher Vocational Colleges Based on cross-border E-commerce -- a case study of international trade major in Urban Construction College [J]. Knowledge economy, 2016 (09): 148-149 + 151. 